\title{
The role of urine neutrophil gelatinase - associated lipocalin (NGAL) in acute heart failure in patients with ST - elevation myocardial infarction
}

\author{
Simona Kirbiš ${ }^{1 *}$, Maksimiljan Gorenjak² and Andreja Sinkovič ${ }^{1}$
}

\begin{abstract}
Background: Neutrophil gelatinase-associated lipocalin (NGAL) is a novel early marker of acute kidney injury for which has been shown that it can also be released from the injured myocardium. Our aim was to correlate urine NGAL with markers of in-hospital heart failure in patients with acute ST-elevation myocardial infarction (STEMI).

Methods: We prospectively included 61 consecutive STEMI patients after primary percutaneous coronary intervention and estimated admission and in-hospital urine NGAL, serum creatinine, troponin I, leucocytes, CRP, $\mathrm{N}$-terminal pro brain natriuretic peptide (NT-proBNP) levels and ejection fraction by echocardiography. Urine NGAL levels were compared between patients with and without HF defined as serum NT-proBNP $>400 \mathrm{pmol} / \mathrm{l}$ and were correlated to markers of heart failure, inflammations and of kidney function.

Results: Urine NGAL levels and CRP was significantly higher in participants with heart failure compared to those with NT-proBNP below 400 pmol/l. Urine NGAL level of $50 \mathrm{ng} / \mathrm{ml}$ had $90 \%$ specificity for HF, the sensitivity was low at $25 \%$. Comparison of participants with NGAL levels $<50 \mathrm{ng} / \mathrm{ml}$ and $\geq 50 \mathrm{ng} / \mathrm{ml}$ at admission and after $12 \mathrm{~h}$ revealed a significant difference in NT-proBNP levels, left ventricle ejection fraction, markers of inflammation and of kidney function. Urine NGAL level was independently associated with NT-proBNP level.

Conclusions: The level of urine NGAL early after myocardial infarction is associated with NT-proBNP concentration and even NGAL levels below $137 \mathrm{ng} / \mathrm{ml}$, the usually reported normal cut-off value, had high specificity for HF in our sample.
\end{abstract}

Keywords: Neutrophil gelatinase-associated lipocalin - NGAL, Heart failure, Myocardial infarction, Acute kidney injury

\section{Background}

In spite of early contemporary reperfusion therapy by primary percutaneous coronary intervention (PPCI), STelevation myocardial infarction (STEMI) can lead to systolic and/or diastolic dysfunction with decreased cardiac output, leading to further decrease in systemic and coronary perfusion and activation of inflammation. It has been shown that inflammation plays an important role in acute heart failure (HF) after acute myocardial infarction (MI) and there is evidence for profound neutrophil activation during acute MI with release of proinflammatory markers $[1,2]$. Inflammation is also important in

\footnotetext{
*Correspondence: simona.kirbis@gmail.com

${ }^{1}$ Department of intensive care unit, University Clinical Center Maribor, Ljubljanska 5, Maribor, SI 2000, Slovenia

Full list of author information is available at the end of the article
}

the process of remodeling by influencing matrix degeneration and fibrosis, promoting apoptosis etc. [3-5].

Neutrophil gelatinase-associated lipocalin (NGAL) is a $25 \mathrm{kDa}$ glycoprotein of the lipocalin superfamily, synthesized in granulocyte precursors in bone marrow during a narrow window of their maturation. It is stored in specific granules of mature neutrophils in complex with gelatinase $[6,7]$. In recent years, NGAL has been considered mainly a predictor of acute kidney injury (AKI), because its plasma and urine levels rise before any increase in creatinine level is encountered [8]. In addition, NGAL has been associated with cell death, inflammation and matrix degradation and there is increasing evidence for enhanced systemic and myocardial expression of NGAL after acute MI, supporting the role of inflammation in this entity [9-12]. 
The aim of our present study was to evaluate the association of urine NGAL early after acute STEMI with markers of myocardial dysfunction and test its predictive value for acute $\mathrm{HF}$.

\section{Methods}

\section{Study design and participants}

We performed an observational prospective monocentric study with patients admitted with acute STEMI to the Department of Medical Intensive Care (ICU), University Medical Centre Maribor. The study was approved by the Republic of Slovenia National Medical Ethics committee (77/01/11) and written informed consent was obtained from all patients. The study protocol conformed to the ethical guidelines of the Declaration of Helsinki.

Consecutive patients admitted with STEMI between April 2010 and July 2011 who had PPCI performed and stayed at the ICU for at least $24 \mathrm{~h}$ were included in the study. Criteria for STEMI were ischemic chest pain lasting up to $12 \mathrm{~h}$ plus persistent ST-elevation or new bundle-branch block on ECG [13]; PPCI is the primary reperfusion strategy for acute STEMI at our institution. Exclusion criteria were prior malignancy, infectious disease, sepsis and death or discharge from the ICU in less than $24 \mathrm{~h}$.

\section{Treatment protocol}

On admission, blood samples were drawn to estimate complete blood cell count, serum troponin I, creatinine and lipid profile and a urine sample was collected for estimation of urine-NGAL. Immediately after PPCI, patients were transferred from the catheterization laboratory to the medical ICU for continuous ECGmonitoring and pulse oximetry. On admission to the ICU, a clinical examination and standard ECG were performed and the patency of peripheral intravenous catheter, inserted before the PPCI, was checked. In case of hemodynamic compromise, the treating physician assessed the need for invasive monitoring. Combined antiplatelet therapy (acetylsalicylic acid and clopidogrel), initiated either in the emergency department or by outpatient emergency units, was continued, statins and angiotensin-converting enzyme inhibitors were administered to all patients unless contraindicated. After admission to the ICU, all patients were started on intravenous saline infusions 0.5 to $1.0 \mathrm{ml} / \mathrm{kg} /$ hour, the total amount of fluid administered depended on clinical signs of acute pulmonary congestion [14].

Complete blood cell count, troponin I, serum creatinine, $\mathrm{N}$-terminal pro brain natriuretic peptide (NT-proBNP) and CRP levels were estimated daily from blood samples collected between 8.00 and 10.00 a.m. in the first two days, later these tests were performed at the discretion of the treating physician. For the study purposes, a urine sample was taken for estimation of NGAL $12 \mathrm{~h}$ after admission and serum creatinine level was estimated every $6 \mathrm{~h}$ during the first $24 \mathrm{~h}$. Two dimensional transthoracic echocardiography was performed within the first $24-48 \mathrm{~h}$. The biplane method of disks (modified Simpson's rule) was used to calculate left ventricular ejection fraction (EF); values higher than $55 \%$ are considered normal [15]. Other investigations and treatment modalities were indicated by the ICU team individually for each patient. During treatment, we obtained data on prior known arterial hypertension, diabetes, dyslipidemia, prior stroke, prior MI, smoking and physical activity.

For the purpose of this study, HF was defined as NTproBNP $\geq 400 \mathrm{pmol} / \mathrm{l}$, in accordance with the European guidelines [16]. Other estimates of heart failure were the Kilip-Kimbal classification and ejection fraction of the left ventricle.

\section{Laboratory methods}

The lipid profile - total serum cholesterol, HDL-cholesterol and triglycerides were estimated by the colorimetric method (Ektachem 250 Analyzer, Eastman Kodak Company, Rochester, USA). Urine NGAL by the chemiluminiscent microparticle immunoassay (CMIA) for the quantitative determination of neutrophil gelatinase-associated lipocalin in human urine (Abbott ARCHITECTAnalyzer, Abbott Ireland Diagnostics Division, Lisnamuck, Ireland; normal levels up to $131.7 \mathrm{ng} / \mathrm{ml}$ - coefficient of variability $4.6 \%$ ). Troponin I was estimated by colorimetric-immune method (Siemens Healthcare Diagnostics Inc., Newark, USA, normal levels up to $0.045 \mu \mathrm{g} / \mathrm{l})$. Plasma NT-proBNP levels was estimated by the electrochemiluminescence immunoassay on an Elecsys 2010 analyzer (Roche Diagnostics, normal levels up to $20 \mathrm{pmol} / \mathrm{L})$. Complete blood cell count was performed by automatic counter Sysmex XE - 2100, Kobe Japan; normal levels for leukocytes were $4-10 \times 10^{9} / \mathrm{l}$, erythrocytes $4.2-6.3 \times 10^{12} / 1$ and platelets $140-340 \times 10^{9} / 1$.

\section{Statistical analysis}

Demographic characteristic and laboratory data were analysed using descriptive methods - frequencies, mean with standard deviation or median with interquartile range. Subgroup comparisons were done using $\chi^{2}$ test for categorical and Student's $t$-test or the nonparametric Mann-Whitney test for numeric variables. Bivariate correlations were tested by Spearmann's coefficient (rho). $P$ value of 0.05 was set as the limit of statistical significance. SPSS Statistics 18.0 (IBM ${ }^{\circ}$ ) was used for statistical analysis.

Sensitivity and specificity of NGAL concentration for heart failure defined by elevated NT-proBNP level 
was calculated [16]. A receiver operating characteristic (ROC) diagram was constructed with urine NGAL level as the test variable and NT-proBNP level as the state variable (Fig. 3). Area under the curve of the constructed ROC diagram was 0.67 (95 \% CI 0.52, $0.83 ; p=0.02)$. Although the area under the curve was relatively low, it still was considered relevant. The cut-off of urine NGAL with $90 \%$ specificity for heart failure was $46.95 \mathrm{ng} / \mathrm{ml}$, the sensitivity of this cut-off was $25 \%$; the value $50 \mathrm{ng} / \mathrm{ml}$ was used in addition to the previously established normal value of $137 \mathrm{ng} / \mathrm{ml}$. This $50 \mathrm{ng} / \mathrm{ml}$ cut-off was thus derived from the same dataset as used in all other statistical analyses.

Urine NGAL levels, markers of kidney injury and markers of inflammation were compared between predefined subgroups of patients with NT-proBNP $<400 \mathrm{pmol} / \mathrm{l}$ and patients with NT-proBNP $\geq 400 \mathrm{pmol} / \mathrm{l}$. Conversely, markers of heart failure, inflammation and kidney injury were compared in subgroups based on values of urine NGAL. A linear regression model was constructed with NT-proBNP as the dependent and age, gender, NGAL level, CRP, peak creatinine and left ventricular ejection fraction as independent variables.

\section{Results}

In total, 61 patients were included in the study, among them $44(72 \%)$ men. The mean age was 63.8 years (SD 12.8 years) As shown in Fig. 1, the most prevalent risk factor for vascular disease was arterial hypertension, followed by dyslipidemia and diabetes.

Among the studied patients, 39 were in Kilip class I, 11 in Kilip class II, 5 in Kilip class III and 6 in Kilip

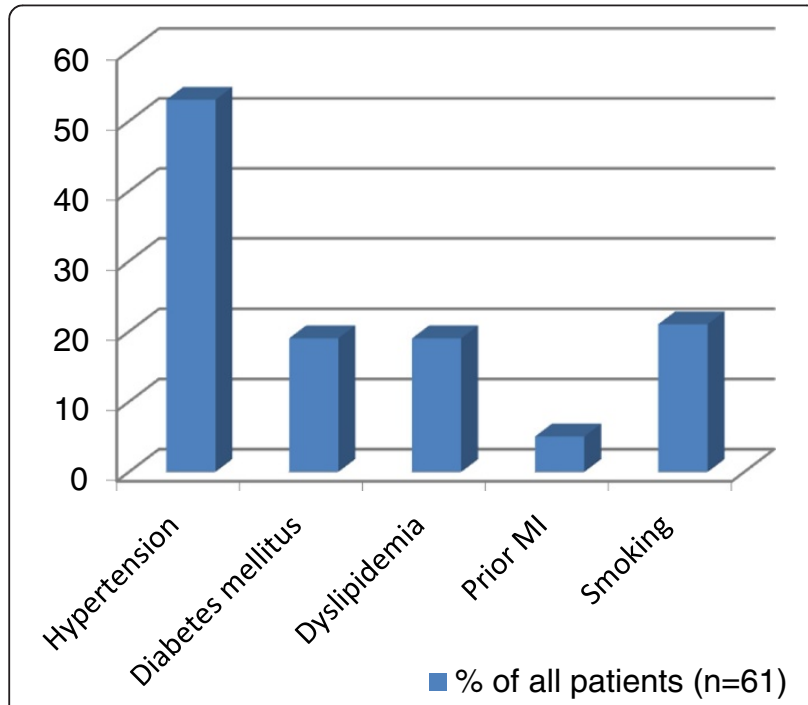

Fig. 1 Risk factors for vascular diseases in study participants. Legend: $\mathrm{Ml}=$ myocardial infarction class IV as the higher class during their stay in the ICU. The average values of analysed laboratory variables in the whole sample are presented in Table 1 and the distribution of NGAL levels stratified by heart failure is presented in Fig. 2. There was no significant difference between NGAL levels at admission and after $12 \mathrm{~h}$ and, overall, the levels were well below the $137 \mathrm{ng} / \mathrm{ml}$ as the usual normal cut-off value. Only two patients had urine NGAL above $137 \mathrm{ng} / \mathrm{ml}$ both at admission and after $12 \mathrm{~h}$.

We compared markers of inflammation and of cardiac function in patients with NT-proBNP levels above and below $400 \mathrm{pmol} / \mathrm{l}$ which was the definition for heart failure in or study ([16]; Table 2). There was a significant difference between subgroups in urine NGAL levels and in markers of inflammation. The subgroups did not differ in the amount of radiologic contrast material infused.

As explained in the methods section, urine NGAL $50 \mathrm{ng} / \mathrm{ml}$ was established as the level with $90 \%$ specificity for acute heart failure defined by NT-proBNP (Fig. 3). Comparison of the two subgroups with NGAL levels $<50 \mathrm{ng} / \mathrm{ml}$ and $\geq 50 \mathrm{ng} / \mathrm{ml}$ at admission and after $12 \mathrm{~h}$ revealed a significant difference in NT-proBNP levels and in ejection fraction as well as in markers of inflammation and of kidney function between subgroups (Table 3). When we used $137 \mathrm{ng} / \mathrm{ml}$ as the cut-off value, subgroups did not differ in any of the analyzed variables.

Because NGAL has high specificity for heart failure after STEMI in our sample, we attempted to establish correlations between NGAL levels and markers of inflammation and of heart failure. There was a positive

Table 1 Admission and in-hospital laboratory data of the included STEMI patients

\begin{tabular}{ll}
\hline Laboratory data $($ mean $\pm \mathrm{SD})$ & $N=61$ \\
\hline Urine NGAL at admission $(\mathrm{ng} / \mathrm{ml})$ & $24.5 \pm 42.1$ \\
Urine NGAL at $12 \mathrm{~h}(\mathrm{ng} / \mathrm{ml})$ & $27.7 \pm 42.7$ \\
In-hospital NT-proBNP $(\mathrm{pmol} / \mathrm{l})$ & $565.0 \pm 882.2$ \\
EF $(\%)$ & $42.2 \pm 12.5$ \\
Troponin I at admission $(\mu \mathrm{g} / \mathrm{l})$ & $12.1 \pm 20.5$ \\
Troponin I after $12 \mathrm{~h}(\mu \mathrm{g} / \mathrm{l})$ & $55.7 \pm 37.0$ \\
CRP at $24 \mathrm{~h}(\mathrm{mg} / \mathrm{l})$ & $99.0 \pm 54.7$ \\
Creatinine at admission $(\mu \mathrm{mol} / \mathrm{l})$ & $102.5 \pm 45.0$ \\
Creatinine at $24 \mathrm{~h}(\mu \mathrm{mol} / \mathrm{l})$ & $99.0 \pm 54.7$ \\
Leucocyte count at $24 \mathrm{~h}\left(1 \times 10^{12} / \mathrm{l}\right)$ & $10.9 \pm 3.9$ \\
Contrast material infused $(\mathrm{ml})$ & $147.2 \pm 67.6$ \\
\hline
\end{tabular}

Data are presented as mean \pm standard deviation

MI myocardial infarction, NGAL neutrophil gelatinase-associated lipocalin, $C R P C$ reactive protein, $E F$ left ventricular ejection fraction, $N T$ - proBNP N-terminal pro brain natriuretic peptide 


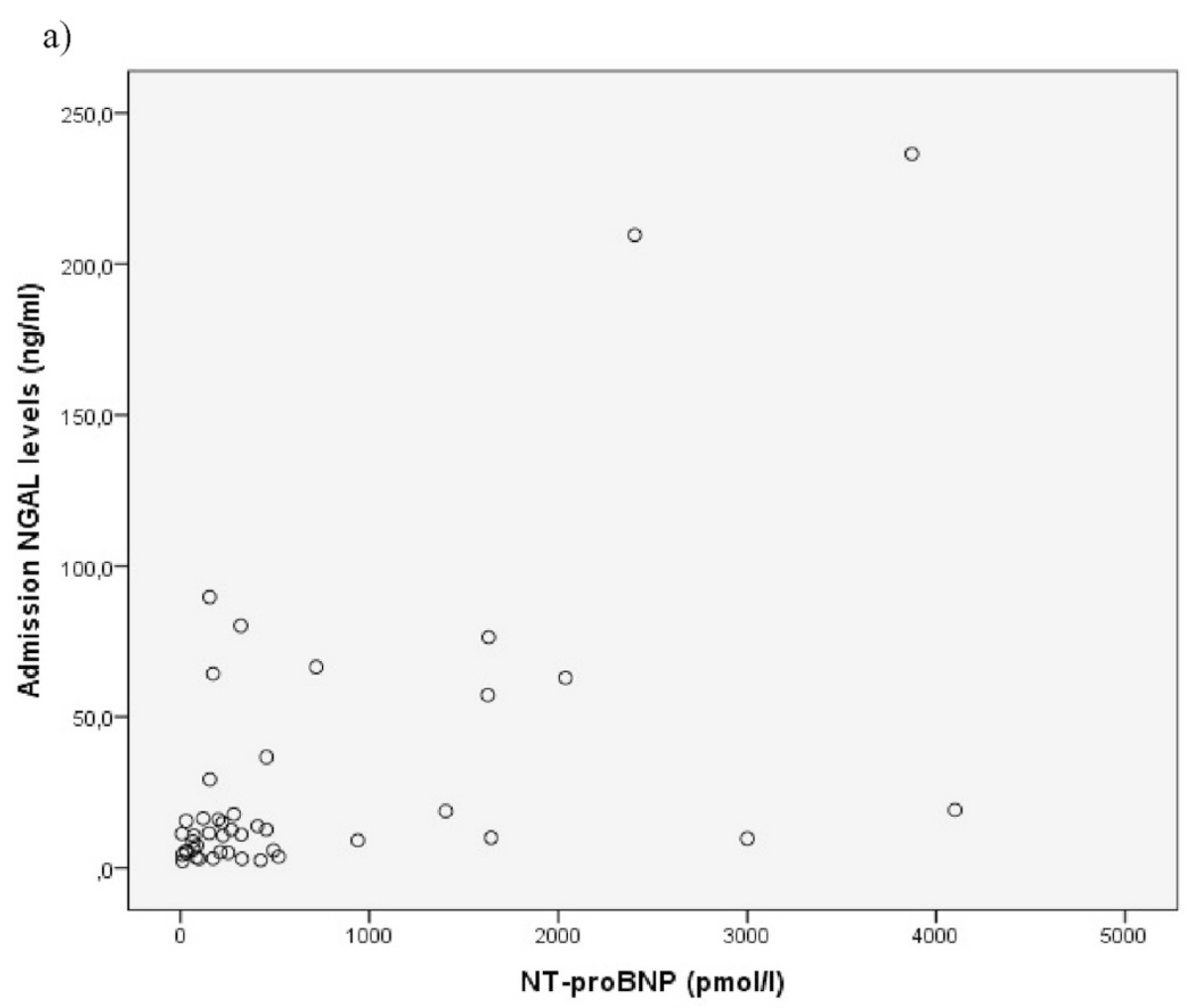

b)

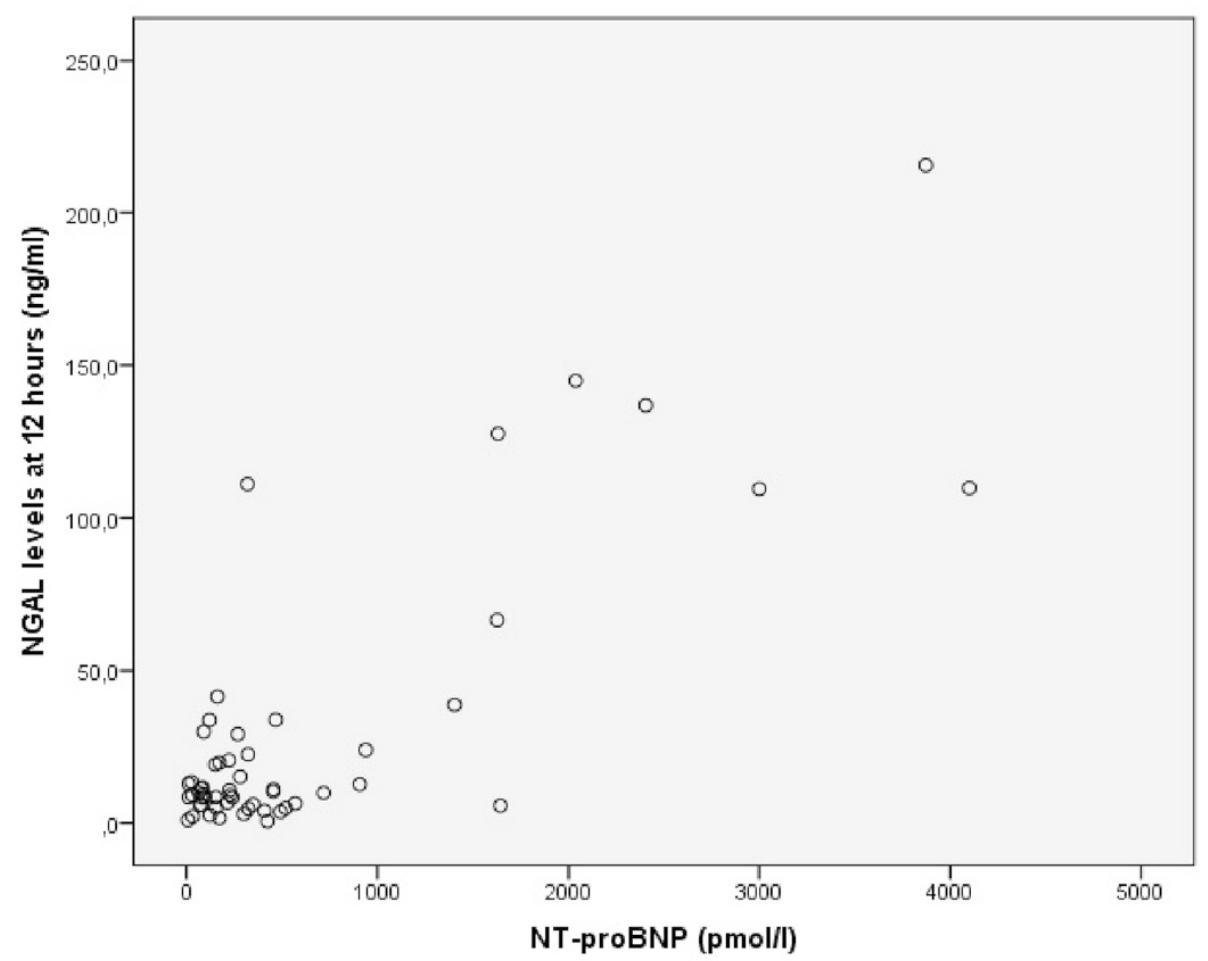

Fig. 2 (See legend on next page.) 
(See figure on previous page.)

Fig. 2 The distribution of urine neutrophil gelatinase-associated lipocalin (NGAL) concentration at admission (a) and $12 \mathrm{~h}$ after admission (b) and its relation to serum N-terminal pro brain natriuretic peptide (NT-proBNP) concentration. a Urine NGAL levels at admission. b Urine NGAL levels $12 \mathrm{~h}$ after admission. Legend: NGAL = neutrophil gelatinase-associated lipocalin; NT - proBNP = N-terminal pro brain natriuretic peptide

association between admission urine NGAL and inhospital NT-proBNP $\left(\mathrm{rho}_{\mathrm{s}} 0.34, p=0.003\right)$ and between admission urine NGAL and in-hospital CRP $\left(\mathrm{rho}_{\mathrm{s}}\right.$ $0.22, p=0.04)$. Results were similar for urine NGAL estimated $12 \mathrm{~h}$ after admission ( $\mathrm{rho}_{\mathrm{s}} 0.34$ for NTproBNP, $p=0.003$ and rho $_{\mathrm{s}} 0.353$ for CRP, $p=0.03$ ). There was a negative association between NGAL on admission and EF (rhos $-0.122, p=0.19$ ). In a multiple linear regression model, urine NGAL levels $(\beta=8.91)$ and female gender $(\beta=464.1)$ were independently associated with NT-proBNP concentration, while age, peak troponin, creatinine and CRP were not; adjusted $\mathrm{r}^{2}$ for model 0.716 .

\section{Discussion}

In our sample of patients with acute STEMI we observed NGAL levels below the usual normal limit $137 \mathrm{ng} / \mathrm{ml}$ in the great majority of participants. However, higher levels of NGAL - even though below the above stated limit - had high specificity for development of heart failure and urine NGAL concentration was positively correlated with serum concentration of NTproBNP. These results suggest that elevated urine NGAL very early after STEMI could be a marker of high risk for acute heart failure in an individual patient and that with regard to MI much lower concentrations of NGAL are of significance compared to when evaluating patients with kidney failure [17].

Urine NGAL was individually correlated with NTproBNP as well as with CRP and creatinine. In a

Table 2 Comparison of subgroups with heart failure and with no heart failure as defined by $\mathrm{N}$-terminal pro brain natriuretic peptide level (NT-proBNP)

\begin{tabular}{|c|c|c|c|}
\hline Variables (mean \pm SD) & $\begin{array}{l}\text { NT-proBNP } \\
<400 \mathrm{pmol} / \mathrm{l} \\
(n=41)\end{array}$ & $\begin{array}{l}\text { NT-proBNP } \\
\geq 400 \mathrm{pmol} / \mathrm{l} \\
(n=20)\end{array}$ & $P$ value \\
\hline EF at $24-48$ h (\%) & $48.1 \pm 7.8$ & $31.3 \pm 11.9$ & $<0.01$ \\
\hline Urine NGAL at admission (ng/ml) & $14.8 \pm 19.2$ & $45.0 \pm 65.2$ & $<0.01$ \\
\hline Urine NGAL at $12 \mathrm{~h}(\mathrm{ng} / \mathrm{ml})$ & $15.5 \pm 18.3$ & $53.8 \pm 63.6$ & $<0.01$ \\
\hline Troponin I at admission $(\mu \mathrm{g} / \mathrm{l})$ & $7.2 \pm 13.0$ & $22.5 \pm 28.7$ & $<0.01$ \\
\hline Creatinine at 24 h ( $\mu \mathrm{mol} / \mathrm{l})$ & $83.7 \pm 28.9$ & $134.0 \pm 79.9$ & $<0.01$ \\
\hline CRP at $24 \mathrm{~h}(\mathrm{mg} / \mathrm{l})$ & $21.3 \pm 23.3$ & $59.5 \pm 74.9$ & $<0.01$ \\
\hline Leucocytes at $24 \mathrm{~h}\left(1 \times 10^{12} / \mathrm{l}\right)$ & $10.1 \pm 3.0$ & $12.6 \pm 5.1$ & $<0.01$ \\
\hline Amount of contrast material (ml) & $142.0 \pm 67.3$ & $160.3 \pm 69.6$ & NS \\
\hline
\end{tabular}

Data are presented as mean \pm standard deviation

$M I$ myocardial infarction, NGAL neutrophil gelatinase-associated lipocalin, $C R P C$ reactive protein, $E F$ left ventricular ejection fraction, NT-proBNP N-terminal pro brain natriuretic peptide multiple linear regression model, NGAL was an independent predictor of NT-proBNP concentration, even though in clinical terms the association was weak. This association and the correlation between NGAL and CRP can be viewed as evidence for the importance of early inflammation in acute heart failure after MI. But we must state that NGAL has several possible sources most commonly is has been associated with inflammation and with kidney dysfunction - and that our study design does not allow deductions about causality.

Damman et al. have shown that increased urine NGAL is highly prevalent in patients with chronic HF and, similarly to our results, positively associated with increased levels of NT-proBNP [18]. Other authors have demonstrated that in patients with chronic HF of ischemic origin with normal renal function, serum NGAL levels were markedly increased in comparison to controls and this increase independently correlated with New York heart Association (NYHA) class and the estimated glomerular filtration rate [19]. It has also been demonstrated that plasma NGAL strongly predicted mortality in patients with chronic heart failure with and without chronic kidney disease [20]. Our results suggest

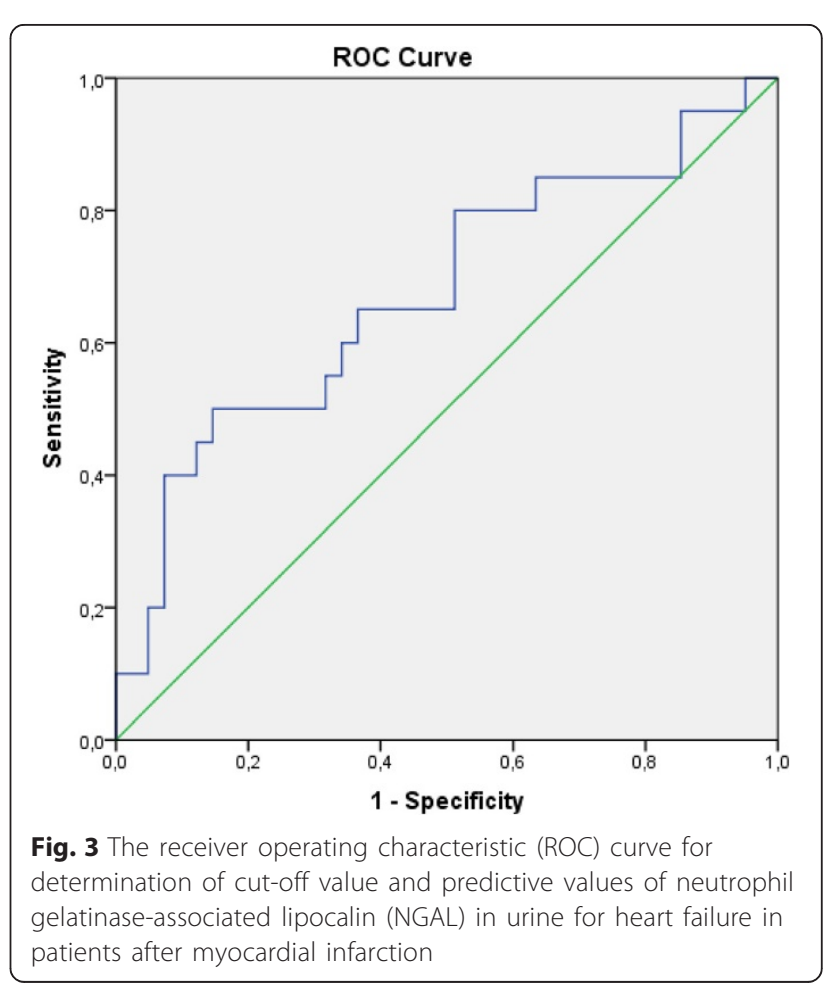


Table 3 Admission and in-hospital laboratory findings by urine NGAL

\begin{tabular}{|c|c|c|c|c|c|c|}
\hline Variables & $\begin{array}{l}\text { Admission urine NGAL } \\
<50 \mathrm{ng} / \mathrm{ml}(n=52)\end{array}$ & $\begin{array}{l}\text { Admission urine NGAL } \\
\geq 50 \mathrm{ng} / \mathrm{ml}(n=9)\end{array}$ & $p$ & $\begin{array}{l}\text { Urine NGAL after } 12 \mathrm{~h} \\
<50 \mathrm{ng} / \mathrm{ml}(n=52)\end{array}$ & $\begin{array}{l}\text { Urine NGAL after } 12 \mathrm{~h} \\
\geq 50 \mathrm{ng} / \mathrm{ml}(n=9)\end{array}$ & $p$ \\
\hline JT-proBNP after 24 h (pmol/l) & $218.0(82.5-420.0)$ & $1627.0(245.50-2221.5)$ & $p<0.05$ & $214.0(84.0-424.0)$ & $2221.5(1628.0-3654.0)$ & $p<0.05$ \\
\hline $\mathrm{EF}(\%)$ & $47(35-50)$ & $25(20-40)$ & $p<0.05$ & $45(35-50)$ & $20(20-36.2)$ & $p<0.05$ \\
\hline Kilip $\geq 2$ (\%) & 22 & 78 & $p<0.05$ & 22 & 78 & $p<0.05$ \\
\hline Leucocytes after 24 h ( 1 × 1012/l) & $9.2(7.8-12.1)$ & $14.3(8.5-16.3)$ & NS & $9.2(7.8-11.6)$ & $14.3(8.9-16.5)$ & NS \\
\hline CRP after $24 \mathrm{~h}(\mathrm{mg} / \mathrm{l})$ & $16.0(10.0-30.0)$ & $32.0(6.5-140.5)$ & NS & $15.0(7-28.5)$ & $80.0(36.0-177.8)$ & $p<0.05$ \\
\hline Creatinine admission $(\mu \mathrm{mol} / \mathrm{l})$ & $91.0(69.8-114.0)$ & $140.0(100.0-216.0)$ & $p<0.05$ & $92.0(74.0-114.0)$ & $153.0(111.0-217.0)$ & $p<0.05$ \\
\hline Creatinine after $24 \mathrm{~h}(\mu \mathrm{mol} / \mathrm{l})$ & $78.5(63.0-94.5)$ & $142.0(94.5-273.0)$ & $p<0.05$ & $78.0(63.5-93.5)$ & $198.5(133.8-275)$ & $p<0.05$ \\
\hline Contrast material (ml) & $140.0(110.0-178.6)$ & $90.0(61.5-198.8)$ & NS & $135.0(100.0-168.0)$ & $174.2(110.0-240.0)$ & NS \\
\hline
\end{tabular}

Data are presented as median (interquartile range) for numeric and as proportions for categorical variables

$N G A L$ neutrophil gelatinase-associated lipocalin, $C R P C$ reactive protein, $E F$ left ventricular ejection fraction, $N T$ - proBNP N-terminal pro brain natriuretic peptide

that NGAL is also associated with markers of acute HF also in the setting of STEMI and this in probably independent of kidney function. Previous (chronic) heart failure is a possible confounding factor, but unfortunately, we did not have reliable enough data about past cardiac function in our participants.

Kidney damage is another possible cause of elevated NGAL. After STEMI, kidney injury may be the consequence of different mechanisms including systolic dysfunction, nephrotoxicity of contrast material used during PPCI, other nephrotoxic drugs, activation of sympathetic and renin-angiotensin-aldosterone system, inflammation and oxidative stress. NGAL can be released by activated neutrophil, epithelial and endothelial cells, smooth muscle cells and cells in in atherosclerotic plaques $[19,21]$. Aghel et al. revealed that patients who developed worsening renal function during hospitalization had significantly higher median admission serum NGAL levels (admission NGAL levels $\geq 140 \mathrm{ng} / \mathrm{ml}$ ) [22]. In our patients, the mean creatinine level was near normal and no one required renal replacement therapy. The amount of contrast material did not differ between patients with and without heart failure nor between patients with NGAL levels above and below $50 \mathrm{ng} / \mathrm{ml}$ and we therefore assume that kidney failure is unlikely the sole explanation for elevated NGAL in patients with heart failure in our sample. Palazzuoli et al. showed that NGAL levels above $130 \mathrm{ng} / \mathrm{ml}$ predicted not only renal injury, but also an overall risk for cardiac events [17]. According to our data, the NGAL levels predicting heart failure are even lower.

\section{Study limitations}

Several limitations may influence our results. We studied urine NGAL concentrations, which may follow a different timeline than serum concentration and have a different relationship with kidney damage compared to serum concentration. We also had no data on prior heart failure, which has been shown to influence NGAL levels [18]. Importantly, the cut-off value of urine NGAL with high specificity for HF $(50 \mathrm{ng} / \mathrm{ml})$ was derived from the analyzed sample itself and this will have to be verified in other, larger samples. Patients who were discharged from the ICU within $24 \mathrm{~h}$ were excluded from the study and this diminished the number of participants with a possible bias towards more severe cases.

\section{Conclusions}

The level of urine NGAL early after myocardial infarction is associated with NT-proBNP concentration and even NGAL levels below $137 \mathrm{ng} / \mathrm{ml}$, the usually reported normal cut-off value, had high specificity for HF in our sample. The mechanism of urine NGAL increase after STEMI and its potential value as a predicting factor for acute HF should be investigated in further studies.

\section{Competing interests}

The authors declare that they have no competing interests.

\section{Authors' contributions}

SK: concept/design, data collection and analysis/interpretation/drafting article/approval of the submitted and final versions. AS: concept/design, data analysis/statistics, revising article critically/ approval of the submitted and final versions. MG: laboratory analysis/approval of the submitted and final version. All authors read and approved the final manuscript.

\section{Author details}

${ }^{1}$ Department of intensive care unit, University Clinical Center Maribor, Ljubljanska 5, Maribor, SI 2000, Slovenia. ²Department of laboratory diagnostics, University Clinical Center Maribor, Maribor, Slovenia.

Received: 23 February 2015 Accepted: 1 June 2015

Published online: 13 June 2015

\section{References}

1. Elneihoum AM, Falke P, Hedblad B, Lindgarde F, Ohlsson K. Leukocyte activation in atherosclerosis: correlation with risk factors. Atherosclerosis. 1997;131:79-84

2. Falke P, Elneihoum AM, Ohlsson K. Leukocyte activation: relation to cardiovascular mortality after cerebrovascular ischemia. Cerebrovasc Dis. 2000;10:97-101.

3. Hochman JS. Cardiogenic shock complicating acute myocardial infarction: expanding the paradigm. Circulation. 2003;107:2998-3002. 
4. Reynolds HR, Hochman JS. Cardiogenic shock: current concepts and improving outcomes. Circulation. 2008;117:686-97.

5. Kirbis S, Breskvar UD, Sabovic M, Zupan I, Sinkovic A. Inflammation markers in patients with coronary artery disease - comparison of intracoronary and systemic levels. Wien Klin Wochenschr. 2010;122:31-4.

6. Kjeldsen L, Bainton DF, Sengelov $H$, Borregaard N. Identification of neutrophil gelatinase-associated lipocalin as a novel matrix protein of specific granules in human neutrophils. Blood. 1994;83:799-807.

7. Kjeldsen $L$, Johnsen $A H$, Sengelov $H$, Borregaard N. Isolation and primary structure of NGAL, a novel protein associated with human neutrophil gelatinase. J Biol Chem. 1993;268:10425-32.

8. Ronco C. N-GAL: diagnosing AKI as soon as possible. Crit Care. 2007;11:173.

9. Malyszko J, Bachorzewska G, Malyszko JS, Pawlak K, Dobrzycki S. Serum neutrophil gelatinase-associated lipocalin as a marker of renal function in hypertensive and normotensive patients with coronary artery disease. Nephrology. 2008;13:153-6.

10. Vinten-Johansen J. Involvement of neutrophils in the pathogenesis of lethal myocardial reperfusion injury. Cardiovasc Res. 2004;61:481-97.

11. Tang WH, Brennan ML, Philip K, Tong W, Mann S, Van Lente F, et al. Plasma myeloperoxidase levels in patients with chronic heart failure. Am J Cardiol. 2006:98:796-9.

12. Tang WH, Tong W, Troughton RW, Martin MG, Shrestha K, Borowski A, et al. Prognostic value and echocardiographic determinants of plasma myeloperoxidase levels in chronic heart failure. J Am Coll Cardiol. 2007:49:2364-70.

13. Van de Werf F, Blomstrom-Lundqvist CB, Crea F, Falk V, Filippatos G, Fox K et al. Management of acute myocardial infarction in patients presenting with persistent ST-segment elevation-ESC guidelines. Eur Heart J. 2008;29:2909-45.

14. Wijns W, Kolh P, Danchin N, Di Mario C, Falk V, Folliguet $T$, et al. Guidelines on myocardial revascularization. The task force on myocardial revascularization of the European society of cardiology (ESC) and the European association for cardio-thoracic surgery. Eur Heart J. 2010;31(20):2501-55.

15. Lang RM, Bierig M, Devereux RB, Flachskampf FA, Pelikka PA, Picard MH, et al. Recommendations for chamber quantification: a report from the American society of echocardiography's guidelines and standards committee and the chamber quantification writing group, developed in conjunction with the European association of echocardiography, a branch of the European society of cardiology. J Am Soc Echocardiogr. 2005;18:1440-63.

16. Dickstein K, Cohen-Solal A, Filippatos G, McMurray JJV, Ponikowski P, Poole-Wilson PA, et al. ESC guidelines for the diagnosis and treatment of acute and chronic heart failure 2008. The task force for the diagnosis and treatment of acute and chronic heart failure 2008 of the European society of cardiology. Developed in collaboration with the Heart failure Association of the ESC (HFA) and endorsed by the European society of intensive care medicine (ESCIM). Eur J Heart Fail. 2008;10:933-89.

17. Palazzuoli A, Ruocco G, Beltrami M, Franci B, Pellegrini M, Lucani B, et al. Admission plasma neutrophil gelatinase-associated lipocalin (NGAL) predicts worsening renal function during hospitalization and post discharge outcome in patients with acute heart failure. Acute Card Care. 2014, (early Online).

18. Damman K, van Veldhuisen DJ, Navis G, Voors AA, Hillege HL. Urinary neutrophil gelatinase associated lipocalin (NGAL), a marker of tubular damage, is increased in patients with chronic heart failure. Eur J Heart Fail. 2008;10:997-1000.

19. Bolignano D, Basile G, Parisi P, Coppolino G, Nicocia G, Buemi M. Increased plasma neutrophil gelatinase-associated lipocalin levels predict mortality in elderly patients with chronic heart failure. Rejuvenation Res. 2009;12:7-14.

20. Van Deursen VM, Damman K, Voors AA, Van der Wal MH, Jaarsma T, Van Veldhuisen DJ, et al. Prognostic value of plasma neutrophil gelatinaseassociated lipocalin for mortality in patients with heart failure. Circ Heart Fail. 2014;7(1):35-42.

21. Yndestad $A$, Landro $L$, Ueland $T$, Dahl $C P$, Flo TH, Vinge $L E$, et al. Increased systemic and myocardial expression of neutrophil gelatinase-associated lipocalin in clinical and experimental heart failure. Eur Heart J. 2009;30:1229-36.

22. Aghel A, Shrestha K, Mullens W, Borowski A, Tang WH. Serum neutrophil gelatinase-associater lipocalin (NGAL) in predicting worsening renal function in acute decompensated heart failure. J Card Fail. 2010;16:49-54.

\section{Submit your next manuscript to BioMed Central and take full advantage of:}

- Convenient online submission

- Thorough peer review

- No space constraints or color figure charges

- Immediate publication on acceptance

- Inclusion in PubMed, CAS, Scopus and Google Scholar

- Research which is freely available for redistribution

Submit your manuscript at www.biomedcentral.com/submit 